\title{
ANALYSIS OF THE ACHIEVEMENT OF THE MINIMUM SERVICE STANDARD SEE FROM THE QUALITY OF SERVICE AND PATIENT SATISFACTION IN THE INSTALLATION OF PHARMACEUTICAL PHARMACEUTICALS IN RSI MALANG "UNISMA"
}

\author{
Musyrifah $^{1}$, Sentot Imam Suprapto ${ }^{2}$, Nia Sari $^{3}$ \\ ${ }^{1}$ Magister of Public Health Program, Stikes Surya Mitra Husada Kediri, Indonesia \\ ${ }^{2,3}$ Lecturer of Magister of Public Health Program, Stikes Surya Mitra Husada Kediri, Indonesia \\ Corresponding author: Musyrifah (musyrifah1705@yahoo.com)
}

\begin{abstract}
Facing the era of intense competition that needs to be trained by hospitals is patient satisfaction, patient satisfaction is closely related to quality service quality and service quality is evaluated by achieving minimum service standards that are in accordance with standards. The existence of preliminary data from the RSI about pharmacy service satisfaction figures in terms of facilities $95.2 \%$, waiting time $77.4 \%$, friendliness $95.2 \%$, accuracy $91.9 \%$, where this data still needs more in-depth research to obtain satisfaction figures valid. The purpose of this study was to determine the effect of service quality on patient satisfaction and the achievement of Minimum Service Standards for outpatient pharmacy installation in Malang Hospital "Unisma". This type of research is quantitative with observational analytic using cross sectional. The population in this study were all patients who visited who had received medication services, taking samples by simple random sampling of 136 samples, using questionnaires. Analyze data with path analysis. The results showed that the path coefficient of Service Quality to satisfaction of 0.425 showed a positive effect. The path coefficient of Service Quality towards achievement of MSS of 0.413 shows a positive influence, the path coefficient of Patient Satisfaction with achievement of MSS of 0.166 shows a positive influence. To improve the quality of service, it will be followed by achieving good standards, so patient satisfaction will also increase. From the results of this study it can be concluded that the better the Quality of Service, the better Patient Satisfaction. The better the Quality of Service, the better the Achievement of Minimum Service Standards and the better the Patient Satisfaction, the better the Quality of Service Standards.
\end{abstract}

Keywords: Service quality, patient satisfaction, minimum service standards

Copyright (C) 2019 Stikes Surya Mitra Husada. All right reserved.

\section{INTRODUCTION}

Pharmaceutical services are a direct service to patients, one of the pharmaceutical service goals, which is to protect patients and communities from irrational use of drugs in the context of patient safety (Anonymous, 2014).

Optimal service needs to be supported by the quality of services, providing information, education and monitoring drug use by pharmacists to ensure the patient's therapeutic goals have been achieved and are well-documented. (Yoga, 2017).

Service quality is a measure of how well the level of service provided is able to meet customer expectations. Based on this definition service quality is determined by the company's ability to meet customer needs and desires according to customer expectations. (Tjiptono, Chandra and Andriana, 2011).

To measure the level of service quality, especially in hospitals, it is measured by assessing the level of customer satisfaction. Satisfaction is a function of the impression of performance and hope. New patients will feel satisfied if the performance of health services obtained is the same or exceeds 
their expectations and vice versa, dissatisfaction or feelings of patient disappointment will arise if the performance of health services obtained is not in line with expectations (Kotler, Philip and Gary Armstrong. 2012). Facing the era of intense competition the main thing that needs to be considered by hospitals is customer satisfaction in order to survive, compete to maintain existing markets.

As preliminary data for research, satisfaction figures for Outpatient Pharmacy Installation in Malang Islamic Hospital "Unisma" have been measured, satisfaction figures in terms of facilities, energy and waiting time, where the achievement for facilities is $95.2 \%$, waiting time is $77.4 \%$, hospitality $95.2 \%$, accuracy of $91.9 \%$ still needs to be discussed more deeply.

The purpose of this study was: To determine the effect of service quality on patient satisfaction and achievement of the Minimum Service Standard (SPM) Outpatient Pharmacy Installation in Malang RSI "Unisma".

\section{METHODS}

The type of this research is quantitative conducted by observational analytic using cross sectional design or cross-sectional design. The population in this study were : All patients who had received services at the Outpatient Pharmacy Installation in Malang Unisma Hospital, Sample in this study were: Patients who visited and had received drug service and were willing to become respondents. The sampling technique used is: Probability Sampling Technique with Simple Random Sampling : random sampling from the population.

The instrument used was a patient satisfaction questionnaire on drug service, a questionnaire on the quality of patient care, a sheet of observation on the data of a minimum service standard, a dependent variable (dependent variable) is customer satisfaction and. Minimum Service Standards for Pharmacy Installation while Independent Variables (independent variables) are Quality of Pharmacy Installation services.

Data analysis using descriptive analysis, bivariate analysis was performed to find whether there was influence/relationship of each dependent variable and independent variable. Data analysis using Linear Regression. Multivariate analysis is done using Path Analysis.

\section{RESULTS} results:

This research was conducted at the Malang Hospital "Unisma", with 136 samples, with the

Table 1. Results of service quality frequency distribution

\begin{tabular}{lcccc}
\hline Quality & SB & B & TB & STB \\
\hline Achievement & $24 \%$ & $75 \%$ & $1 \%$ & $0 \%$ \\
\hline
\end{tabular}

For patient service quality states very good there are $24 \%$ patients, and good service quality is $75 \%$, service quality is not good there is $1 \%$ and quality is not very good no or $0 \%, 1 \%$ is not good this percentage is highest in variable speed in service still lacking, facilities and waiting room conditions are less comfortable.

Table 2. Results of frequency distribution of patient satisfaction.

\begin{tabular}{lcccc}
\hline Satisfaction & SB & B & TB & STB \\
\hline Achievement & $29 \%$ & $69 \%$ & $2 \%$ & $0 \%$ \\
\hline
\end{tabular}

For patient satisfaction, it was found that patients who stated that patient satisfaction stated that they were very satisfied were $29 \%$, who stated that they were satisfied $69 \%$, there were $2 \%$ dissatisfied, very dissatisfied $0 \%, 2 \%$ of dissatisfied $2 \%$ who were dissatisfied the most variable is the officer speed and the comfort of the waiting room, this is the same as the assessment of service quality. 
Satisfaction of patients is very satisfied and satisfied reaching 98\%. This shows that patient satisfaction with 14 indicators of satisfaction: drug service flow, ease of service, staff skills, officer discipline, clarity of tasks, expertise in serving drugs, speed, fairness, friendliness, reasonable cost, certainty of cost, certainty of service schedule, comfort of waiting room and security of drug service are good.

Table 3. Results of Frequency Distribution of Quality Service Standards

\begin{tabular}{|c|c|c|c|c|c|c|}
\hline \multirow{2}{*}{ No } & \multirow{2}{*}{ Indicator } & \multirow{2}{*}{ Standars } & \multicolumn{2}{|c|}{ Compliance } & \multirow{2}{*}{ Total } & \multirow{2}{*}{$\begin{array}{c}\% \\
\text { suitability }\end{array}$} \\
\hline & & & Yes & No & & \\
\hline \multirow{3}{*}{1} & Number of speed recipes: & & & & & \\
\hline & a. Non concoction & $<30$ minutes & 100 & 16 & 116 & $74 \%$ \\
\hline & b. Mixture & $<60$ minutes & 8 & 12 & 20 & $6 \%$ \\
\hline 2 & Accuracy of recipes & $100 \%$ & 136 & 0 & 136 & $100 \%$ \\
\hline 3 & Formulary suitability & $100 \%$ & 129 & 7 & 136 & $95 \%$ \\
\hline
\end{tabular}
described :

Based on the table above, the results of the quality service standard frequency distribution are

a. $\quad$ Based on the speed of the recipe, the appropriate recipe speed number is $80 \%$

b. Based on the accuracy of the recipe, 100 percent is obtained according to quality service standards

c. Based on the suitability of the formulary, it was found that 95 percent met the quality service standard.

Crosstab Results

Table 4.4 Quality* Crosstabulation Satisfaction

\begin{tabular}{|c|c|c|c|c|c|}
\hline & & & & action & \\
\hline & & & Satisfied & Very satisfied & Iotal \\
\hline & Food & Count & 89 & 3 & 92 \\
\hline Ouality & Good & $\%$ of Total & $65.4 \%$ & $2.2 \%$ & $67.6 \%$ \\
\hline Vuanimy & Very oood & Count & 13 & 31 & 44 \\
\hline & very goud & $\%$ of Total & $9.6 \%$ & $22.8 \%$ & $32.4 \%$ \\
\hline & Totol & Count & 102 & 34 & 136 \\
\hline & Iotal & $\%$ of Total & $75.0 \%$ & $25.0 \%$ & $100.0 \%$ \\
\hline
\end{tabular}

Table 4.5 Quality * SPM. Crosstabulation speed SPM.

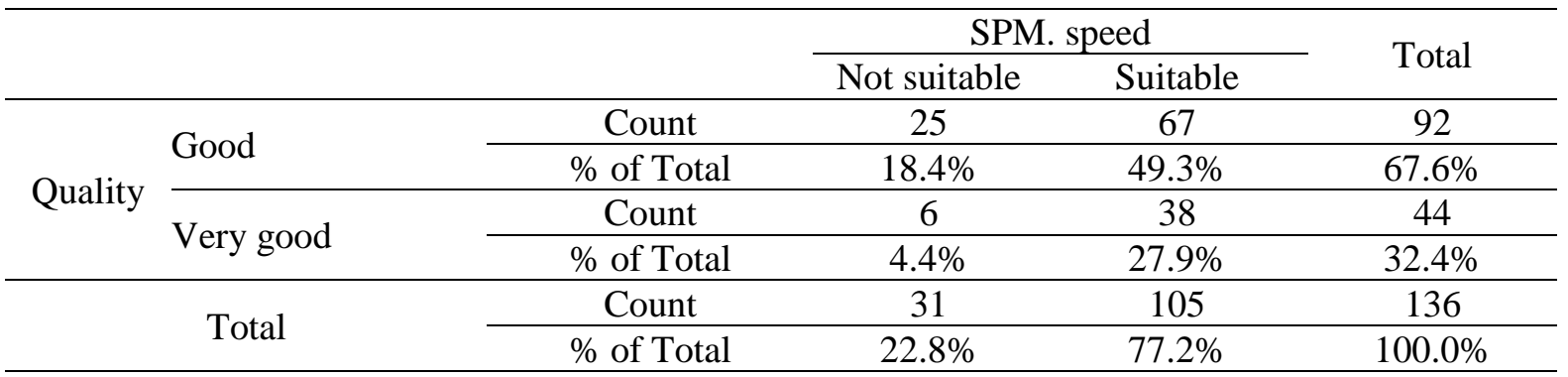


Table 4.6 Quality * SPM. Accuracy of Crosstabulation SPM. Total Accuracy

\begin{tabular}{|c|c|c|c|c|c|}
\hline & & & SPM. & Iracy & \\
\hline & & & Not suitable & Suitable & Total \\
\hline & Good & Count & 1 & 91 & 92 \\
\hline Ouplity & Good & $\%$ of Total & $0.7 \%$ & $66.9 \%$ & $67.6 \%$ \\
\hline Quanty & & Count & 0 & 44 & 44 \\
\hline & Very good & $\%$ of Total & $0.0 \%$ & $32.4 \%$ & $32.4 \%$ \\
\hline & Totol & Count & 1 & 135 & 136 \\
\hline & Total & $\%$ of Total & $0.7 \%$ & $99.3 \%$ & $100.0 \%$ \\
\hline
\end{tabular}

Table 4.7 Quality * SPM. Formulary Crosstabulation Total SPM. Formulary

\begin{tabular}{|c|c|c|c|c|c|}
\hline & & & SPM. & ulary & \\
\hline & & & Not suitable & Suitable & Iotal \\
\hline & Good & Count & 6 & 86 & 92 \\
\hline Ouality & Good & $\%$ of Total & $4.4 \%$ & $63.2 \%$ & $67.6 \%$ \\
\hline Wuamly & Verv oood & Count & 9 & 35 & 44 \\
\hline & & $\%$ of Total & $6.6 \%$ & $25.7 \%$ & $32.4 \%$ \\
\hline & Total & Count & 15 & 121 & 136 \\
\hline & & $\%$ of Total & $11.0 \%$ & $89.0 \%$ & $100.0 \%$ \\
\hline
\end{tabular}

Table 4.8 SPM * Satisfaction. Crosstabulation speed SPM. Total speed

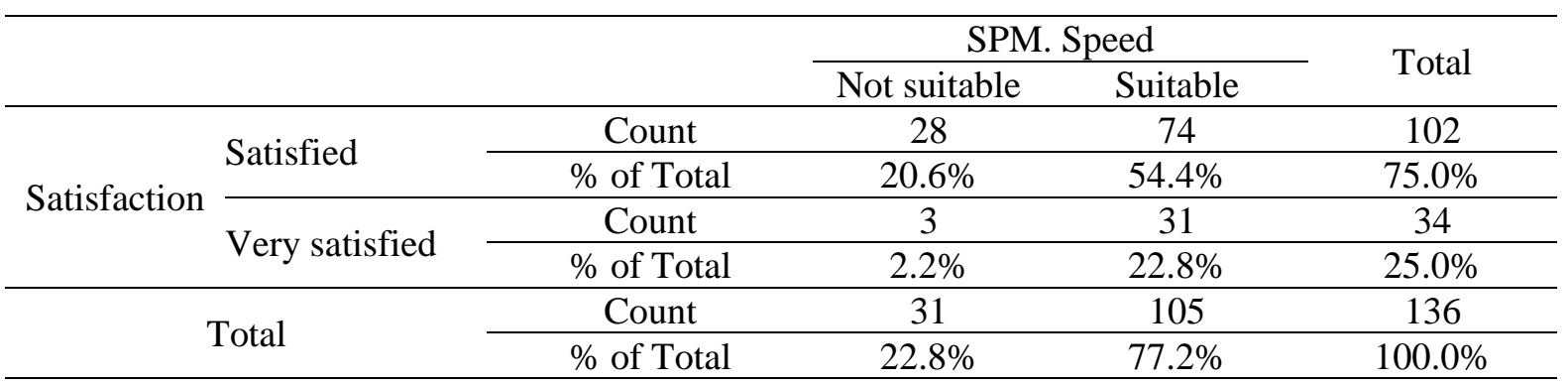

Table 4.9 SPM * Satisfaction. Accuracy of Crosstabulation SPM. Total Accuracy

\begin{tabular}{|c|c|c|c|c|c|}
\hline & & & \multicolumn{2}{|c|}{ SPM. Accuracy } & \multirow{2}{*}{ Total } \\
\hline & & & Not suitable & Suitable & \\
\hline \multirow{4}{*}{ Satisfaction } & \multirow{2}{*}{ Satisfied } & Count & 1 & 101 & 102 \\
\hline & & $\%$ of Total & $0.7 \%$ & $74.3 \%$ & $75.0 \%$ \\
\hline & \multirow{2}{*}{ Very satisfied } & Count & 0 & 34 & 34 \\
\hline & & $\%$ of Total & $0.0 \%$ & $25.0 \%$ & $25.0 \%$ \\
\hline \multirow{2}{*}{\multicolumn{2}{|c|}{ Total }} & Count & 1 & 135 & 136 \\
\hline & & $\%$ of Total & $0.7 \%$ & $99.3 \%$ & $100.0 \%$ \\
\hline
\end{tabular}


Table 4.10 SPM * Satisfaction. Formulary Crosstabulation SPM. Total Formulation

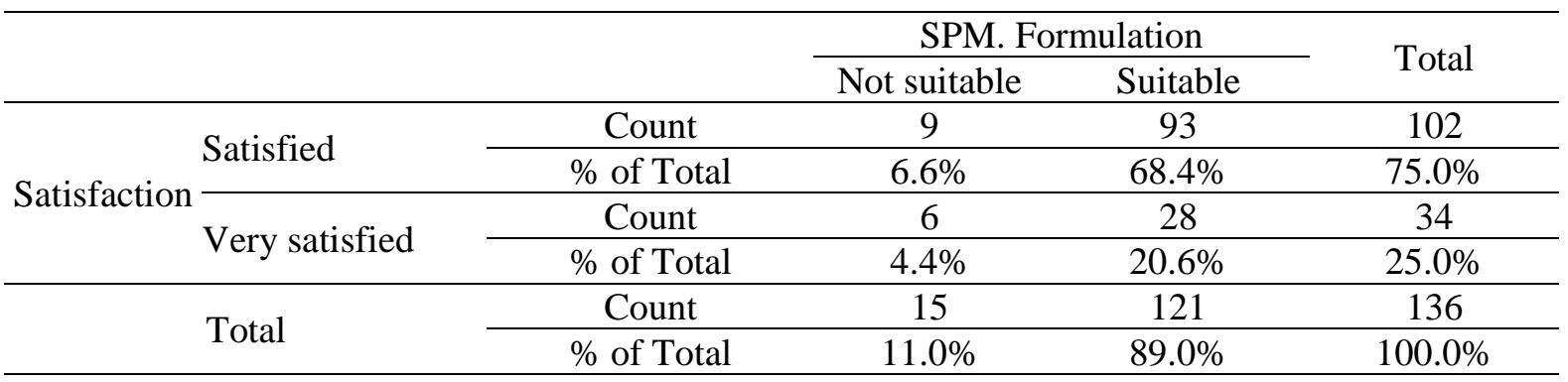

\section{Path analysis}

Path analysis examines the influence between variables, namely the variable Quality of Service, Patient Satisfaction, and Quality of Service Standards.

Table 4. Results of Path Analysis of the First Model of Service Quality for Patient

\begin{tabular}{|c|c|c|c|c|c|c|}
\hline & \multirow{2}{*}{ Model } & \multicolumn{2}{|c|}{ Unstandardized Coefficients } & \multirow{2}{*}{$\frac{\text { Standardized Coefficients }}{\text { Beta }}$} & \multirow{2}{*}{$\mathrm{t}$} & \multirow{2}{*}{ Sig. } \\
\hline & & B & Std. Error & & & \\
\hline \multirow{2}{*}{1} & (Constant) & 37.127 & 1.611 & & 23.050 & .000 \\
\hline & Quality & .186 & .034 & .425 & 5.443 & .000 \\
\hline
\end{tabular}

Source: Processed Research Data (2019)

The path coefficient of Service Quality of 0.425 shows a positive influence, meaning that the better the Quality of Service, the better the Patient Satisfaction.

Table 5. Results of the Second Model Path Analysis of Service Quality and Patient Satisfaction with Quality Service Standards

\begin{tabular}{|c|c|c|c|c|c|c|}
\hline & \multirow[t]{2}{*}{ Model } & \multicolumn{2}{|c|}{$\begin{array}{l}\text { Unstandardized } \\
\text { Coefficients }\end{array}$} & \multirow{2}{*}{$\begin{array}{c}\text { Standardized Coefficients } \\
\text { Beta } \\
\end{array}$} & \multirow[t]{2}{*}{$\mathrm{t}$} & \multirow[t]{2}{*}{ Sig. } \\
\hline & & B & Std. Error & & & \\
\hline \multirow{3}{*}{1} & (Constant) & .498 & .464 & & 1.073 & .285 \\
\hline & Quality & .024 & .005 & .413 & 5.005 & .000 \\
\hline & Satisfaction & .023 & .011 & .166 & 2.014 & .046 \\
\hline
\end{tabular}

Source: Processed Research Data (2019)

Based on the table above can be explained as follows :

a. The service quality coefficient path of 0.413 shows a positive influence, meaning that the better the Quality of Service, the better the Quality of Service Standards.

b. The path coefficient of Patient Satisfaction of 0.166 shows a positive influence, meaning that the better the Patient Satisfaction the better the Quality of Service Standard.

\section{DISCUSSION}

A. Effect of Quality of service on patient satisfaction

The Results of Analysis of Service Quality Paths to Patient Satisfaction, Service Quality Coefficient of 0.425 shows a positive influence, meaning that the better the Quality of Service, the better Patient Satisfaction. 
This is supported by the results of previous studies conducted by Bori and Damanhouri (2013) which show that there is a relationship between tangibles, reliability, responsiveness, safety and empathy that have a significant effect on patient satisfaction, statistically significant in influencing patient satisfaction.

In line with the results of research conducted by Atmawati and Wahyudin (2007) and Ratih Hardiyati (2010), the reliability variable has a positive effect on patient satisfaction.

Service and satisfaction are two things that can not be separated, because with the satisfaction of the parties concerned can mutually correct until where the services provided are better or worse. This is greatly influenced by each officer in providing services, in other words, services that can be satisfactory are services carried out based on applicable regulations.

Basically, an officer is demanded with performance results that must be in accordance with patient expectations, which means timeliness, same service for all patients without errors, sympathetic attitudes, and with high accuracy so that later will give birth to a sense of satisfaction in the patient himself. The better the patient's perception of reliability, the higher patient satisfaction will be. And if the patient's perception of reliability is poor, then patient satisfaction will be lower.

5 (five) principles of service quality namely Reliability, Assurance, Physical Evidence (Tangibel), Attention (Emphaty), Responsiveness (Responsiveness), this must always be considered for hospital services so that service quality is right really awake so that patients will also feel satisfied.

\section{B. Effect of patient satisfaction on achieving minimum service standards.}

Results of Path Analysis of Patient Satisfaction with Achievement of Minimum Service Standards is the path coefficient of Patient Satisfaction of 0.166 indicating a positive influence, meaning that the better the Patient Satisfaction the better the achievement of Minimum Service Standards.

\section{Effect of Quality of service on achieving Minimum Service Standards.}

The Results of Analysis of the Quality of Patients' Pathways to Achieving Minimum Service Standards is good service quality that will produce good SPM values, this is the same result shown in the results of path analysis with Service Quality Path coefficient of 0.413 which shows a positive effect on service quality towards Standards Minimum service.

The program to maintain quality is a continuous, systematic and objective effort in monitoring and assessing services that are carried out compared to established standards, and resolving problems that are found to improve service quality (Maltos \& Keller, 1989).

The standard is the ideal or the highest and perfect level of attainment that is used as a minimum acceptance limit, also referred to as the range of acceptable variations (Clinical Practice Guideline, 1990).

Reliability of officers in providing services to patients. In its implementation, this dimension contains two main elements, namely the ability of institutions to provide services as promised and the accuracy of services provided or how far the officers are able to minimize / prevent errors / errors in the process of services provided. Hospitals / health care facilities will be unreliable if the drug received by the patient turns out to be exchanged with other patients, or other carelessness.

Non-compliance in formulary writing that is appropriate will reduce patient satisfaction in terms of speed, because the officer must confirm the written recipe again, not to mention if the drug is not available, thus increasing service time, this indicates that the minimum service quality standard indicators will also affect patient satisfaction rates.

In order to improve the quality of pharmaceutical services and patient satisfaction, in providing drug services, accuracy is an absolute requirement in serving medicines. Prescription control before prescribing out to patients must be done and done by double check so as to minimize errors.

Non-compliance in formulary writing that is appropriate will reduce service quality in terms of speed, because the officer must confirm the recipe that was written so that it adds to the service time. To find out the quality of service is assessed by patient satisfaction and service quality indicators 
and patient satisfaction also have standards that must be met so that patient satisfaction also affects achievement of standards.

\section{Effect of service quality on achievement of MSS through patient satisfaction}

The results of testing the effect of Service Quality on Quality Service Standards through Patient Satisfaction obtained a path coefficient value of 0.071 and a significance value of 0.049 . This shows a significant positive effect $(p<0.05)$ between Service Quality on Quality Service Standards through Patient Satisfaction, which means that the better Quality of Service will have an impact on the better achievement of Quality Service Standards indirectly through Patient Satisfaction.

This is in accordance with the theory that service quality is a measure of how well the level of service provided is able to meet customer expectations. Based on this definition service quality is determined by the company's ability to meet customer needs and desires according to customer expectations. (Tjiptono, Chandra and Andriana, 2011), so that the quality is in accordance with the customer's desires, there must be a quality indicator to measure how good the service quality is. This is in accordance with the research on the effect of quality on patient satisfaction : Behrouz Pouragha and Ehsan Zarei The Effect Of Outpatient Service Quality On Patient Satisfaction In Teaching Hospitals In Iran.

The main objective of this study was to determine the effect of the quality of outpatient services on patient satisfaction in teaching hospitals in Iran. Management needs to change the mindset from production orientation to marketing orientation with the main emphasis on customer satisfaction. This concept argues that the key to achieving organizational goals consists of determining the needs and desires of the target market and delivering satisfactory products more effectively and efficiently than competitors. To improve customer satisfaction, service providers must provide higher quality services compared to the quality of service consumers / customers expect consistently and continuously. The hospital is an institution that emphasizes service and marketing services.

Above have been explained that service quality can be measured by the existence of minimum service standards where with good quality will increase patient satisfaction, good quality of service can also be seen from patient satisfaction. Similarly, the achievement of maximum standards can show good patient satisfaction.

\section{CONCLUSION}

From the results of the research that has been done it can be concluded that:

1. The Effect of Service Quality on Patient Satisfaction, is the better Quality of Service will have an impact on the better Patient Satisfaction.

2. Effect of Patient Satisfaction on Quality Service Standards, is the better Patient Satisfaction will have an impact on the better Achievement of Minimum Service Standards.

3. Effect of Service Quality on Quality Service Standards, is that the better Quality of Service will have an impact on the better Achievement of Minimum Service Standards.

4. Effect of Service Quality on Achieving Minimum Service Standards, through Patient Satisfaction, which means that the better Quality of Service will have an impact on the better Achievement of Quality Service Standards indirectly increasing Patient Satisfaction.

\section{SUGGESTION}

1. For hospital management:

a. Evaluating the number of staff in the service so that it can improve the quality of services, especially in terms of prescription speed.

b. Improve facilities and infrastructure to support services.

c. A good information system to support fast and accurate services.

d. Dissemination and education to doctors so that prescription is in accordance with the formulary. 
2. For pharmaceutical personnel:

a. Always provide maximum service so that it can satisfy customers, especially accuracy and speed in serving recipes, prescription controls are always routinely carried out for the accuracy of prescription services.

b. Provide clear information to patients about the drugs delivered such as how to use, side effects and how to store.

3. For further researchers :

As a reference for further research in conducting further research on other factors that affect patient satisfaction and its relationship with service quality and minimum service standards.

\section{REFERENCES}

Anonymous. (2004). Decree of the Minister of Health of the Republic of Indonesia Number 1197 / MENKES / SK / X / 2004 concerning pharmaceutical service standards in hospitals. Jakarta: Ministry of Health of the Republic of Indonesia.

Anonim. (2014). Decree of the Minister of Health of the Republic of Indonesia Number 30 of 2014 concerning Standard of Pharmaceutical Services at Hospitals, Ministry of Health of the Republic of Indonesia, Jakarta.

Anonymous. (2014). Government Regulation of the Republic of Indonesia Number 58 concerning Standardization of Medical Services at Hospitals. Republic of Indonesia Ministry of Health. Jakarta.

Assauri, \& Sofjan. (2003). Good customer service Achievement Platform. Customer Satisfaction in Entrepreneurs, No. 01, Year XXXII, January p.25-30: Jakarta.

Bachtiar. (2011). Analysis of Factors Affecting Student Satisfaction in choosing Sawunggalih Polytechnic Aji Purworejo. Socio-Economic Dynamics Vol. 7 No. 1.

Borie, H., M., A., \& Damanhouri, A., M., S. (2013). Patients' satisfaction of service quality in Saudi hospitals: a SERVQUAL analysis. International Journal of Health Care Quality Assurance.

Chairunnisa, C., \& Puspita, M. (2017). "Overview of Patient Satisfaction Outpatient towards Services at Jakarta Sukapura Islamic Hospital (RSIJS) in 2015." Journal of Medicine and Health 13 (1): 9-27.

Kepmenkes, (2008). Minister of Health of the Republic of Indonesia Number 129 / Menkes / SK / II / 2008, concerning Minimum Service Standards for Hospitals of the Ministry of Health of the Republic of Indonesia.

Kotler, P. (2005). Marketing management (Translation). Jakarta: PT. Media Group INDEX. Sampurno. Pharmaceutical marketing management. Yogyakarta: Gadjah Mada University Press.

Kotler, Philip. 2004. Millennium Edition Marketing Management. Jakarta: PT. Gramedia Group Index.

Kotler, Philip, \& Keller, K., L. (2007). Marketing Management. Twelfth Edition Volume 1. Jakarta: Index.

Kotler, Philip, \& Armstrong, G. (2012). Principles of Marketing 13. Edition of Jakarta: Erlangga.

Pouragha, B., \& Zarei, E. (2016). The Effect Of Outpatient Service Quality On Patient Satisfaction In Teaching Hospitals In Iran. Journal of the Academy of Medical Sciences in Bosnia and Herzegovina 
Permenkes. (2016). Regulation of the Minister of Health of the Republic of Indonesia number 72 concerning Standard of Pharmaceutical Services at Hospitals, Ministry of Health of the Republic of Indonesia. Jakarta.

Supriyanto, \& Ernawaty. (2010). "Marketing of the Health Services Industry" Yogyakarta, Andi.

Supartiningsih, S. (2017). Service Quality and Hospital Patient Satisfaction: Cases in Outpatients. Medicoeticolegal Journal and Hospital Management, 6 (1): 9-15.

Sofaer, \& firminger. (2005). Patient perceptions of the quality of health services. Vol. 26: 513-559

Sugiono. (2017). Quantitative, qualitative and R \& D research methods. 26th edition of Alfabeta. Bandung.

Supranto, J. (2006). Measurement of Customer Satisfaction to Increase Market Share. Jakarta.

Tjiptono, Fandy, \& Chandra, G. (2011). Service Quality \& Satisfaction Third edition. Yogyakarta: Andi Offset.

Widyatmoko, A. (2014). "Analysis of Service Quality of the National Health Insurance Program for BPJS Health at the Regional General Hospital in the city of Madiun" Diponegoro University.

Xesfingi, S., et al. (2017). "Patient Satisfaction at Tertiary Level Healthcare Services in Greece: Inpatient vs. Outpatient Healthcare Services Assessment." International Journal of Health Economics and Policy 2 (3): 125.

Yoga, Hanan, Bambang. Profile of prescription service quality by pharmacists at several sub-district pharmacies in Malang city. Pharmaceutical Journal of Indonesia. 